\title{
Reproductive biology of Venus clam Gafrarium tumidum (Roding, 1798) from Southeast coast of India
}

\author{
I. Jagadis \& S. Rajagopal* \\ Regional Centre of Central Marine Fisheries Research Institute, Marine Fisheries, Mandapam Camp, Tamil Nadu, India \\ Correspondence: I Jagadis, Tuticorin Research Centre of Central Marine Fisheries Research Institute, South Beach Road,Tuticorin 628 \\ 001, India. E-mail: ijagadis@sify.com \\ *Present Address: Centre of Advanced Study in Marine Biology, Parangipettai, India.
}

\begin{abstract}
The reproductive biology of tumid venus clam Gafrarium tumidum (Roding) was studied in detail from the Southeast coast of India. Sample size ranged from 10.3 to $41.3 \mathrm{~mm}$. Sexes are separate but not differentiated externally. Annual sex ratio male:female (M:F) deviated significantly from the 1:1 ratio with females dominating. Based on ova diameter progression of gonad smear and histology, four and two maturity stages of gonads were differentiated in female and male clams, respectively. Peak spawning was observed during November and a minor one in April. The monthly average condition index based on wet/ dry flesh weight ranged from 7.24 (November) and 14.14 (September) and 8.82 (October) and 14.38 (August), respectively. The condition index observed by both the methods is comparable and corresponds with the spawning season. Water content observed for male and female clams varied negligibly and showed positive correlation with spawning period. Size at first maturity was estimated to be $22.3 \mathrm{~mm}$.
\end{abstract}

Keywords: spawning, condition index, sex ratio, size at first maturity, Gafrarium tumidum

\section{Introduction}

Bivalves exhibit various types of spawning i.e., single breeding period to year round spawning. The information on sex ratio, sexual maturity and breeding season is helpful in finding out the annual recruitment, assessment of growth and age for judicial exploitation. Preliminary and detailed biological studies have already been carried out on Katelysia opima (Rao 1952), Meretrix casta (Abraham 1953) and Donax cuneatus (Nayar 1955; Rao 1967), Alagarswami
(1966), on Donax faba, Thangavelu and Sanjeevaraj (1985), on M. casta, and Narasimham, Muthiah, Gopinathan and Gandhi (1988) on Meretrix meretrix.

Though extensive studies are made on a number of venerid clams, both in tropical and temperate waters, no information is available on the reproductive pattern of Gafrarium tumidum. This paper deals with gonad maturation, condition index, sex ratio, size at first maturity and spawning season of G. tumidum from the southeast coast of India.

\section{Materials and methods}

Monthly samples of about 50 clams from the natural clam bed at Chinnapalam, Pamban, Southeast coast of India (latitude $8^{\circ} 35^{\prime}-9^{\circ} 25^{\prime} \mathrm{N}$ and Longitude $78^{\circ} 08^{\prime}-$ $79^{\circ} 30^{\prime}$ E.) were collected for 1 year (October' 2000 -September '2001) and used for studying various aspects of maturation. The size range and range of monthly means of the samples were from 10.3 to $41.3 \mathrm{~mm}$ and $24.7-31.5 \mathrm{~mm}$. The sex and the stage of ova developments were ascertained by taking fresh smears of gonad by making a small cut at the middle of the gonad and were examined under light microscope. Fifty ova in each clam were measured using an ocular micrometre precalibrated with a $1 \mathrm{~mm}$ stage micrometre. Measurements in the case of irregular ova (early and late maturing) were taken in two axes and the averages of the values were considered. The gonad smears of the clams were observed at monthly interval continuously for their percentage occurrence. The ovarian stages were classified following Ropes (1968).

For assessing the exact state of gonad and to supplement the data obtained by ova diameter progression, histological preparations were made and studied. Approximately 25 individuals, arbitrarily selected with 
respect to age and stage of gonad development, were excised, fixed in Bouins fixative and prepared for sectioning by dehydration in ethanol and by embedding in paraffin wax at $60-62{ }^{\circ} \mathrm{C}$ (Humason 1972; Kripa 1997) Sections were cut at $8 \mu \mathrm{m}$ thickness and stained with eosin and examined under microscope and classified into different developmental stages. Chi-square test was carried out to ascertain whether the observed sex ratio differed from theoretical 1:1 ratio (Snedecor \& Cochran 1967). The condition index (CI) was calculated as (1) percentage of wet flesh weight in total weight and (2) as percentage of dry flesh weight in wet flesh weight (Narasimham 1988). Difference in the weight between wet and dried body tissues was used to compute the water content of the body tissues. Monthly percentages of maturity stages were worked out and plotted against different size groups to arrive at the size group at which $50 \%$ clams mature. The mean value of this size group was considered as the minimum size at first maturity.

\section{Results}

Sexes are separate in G. tumidum. External differentiation could not be made as well as any recognisable colour difference in the gonad of males and females. In all, four stages in females and two stages in males could be categorized from the observations made on the smear and histological sections.

\section{Gonad smear}

In early maturing clams, the ova were irregular in shape. The average size of the ova was $<45 \mu \mathrm{m}$, in the late maturing stage clams, most of the ova tend to assume a spherical shape and some of them are still irregular in shape. The ova measured between 45 and $58 \mu \mathrm{m}$. In the matured clams, almost all the ova assumed a perfect spherical shape and measured $72 \mu \mathrm{m}$ and above. Very few ova were found to be in a near-spherical shape. In the spent clam, the smear contained only very few perfect spherical ova and measured $72 \mu \mathrm{m}$ and above.

\section{Percentage of maturity stages}

The percentage occurrence of various stages of gonads based on the ova diameter is presented (Fig. 1).

From the figure, the occurrence of all the four maturity stages in all the months of observation in varying percentages was quite evident. Late maturing and matured stages of gonad ranged from 6.5 (November) to $77.5 \%$ (February), respectively. The lowest percentage $(6.5 \%)$ occurrence of late maturing gonad along with highest percentage of spent gonad (80.6\%) were observed during November. Similarly, a lower magnitude of matured gonad (13.1\%) and moderate percentage $(36.1 \%)$ of spent gonad were observed in April. Occurrence of spent gonad was observed throughout the study period in varying magnitude ranging from $6.2 \%$ (August) to $80.6 \%$ (November).

\section{Histology}

Regular observation on the histological preparations yielded valuable data on the progression of the ova.

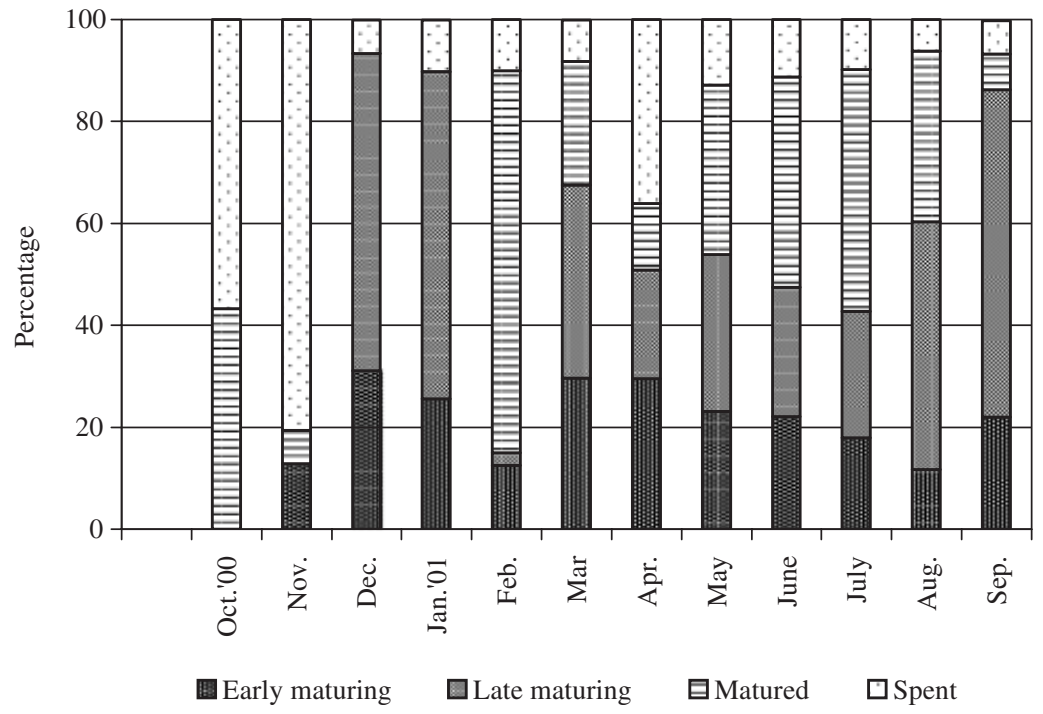

Figure 1 Various stages of maturity in female Gafrarium tumidum. 

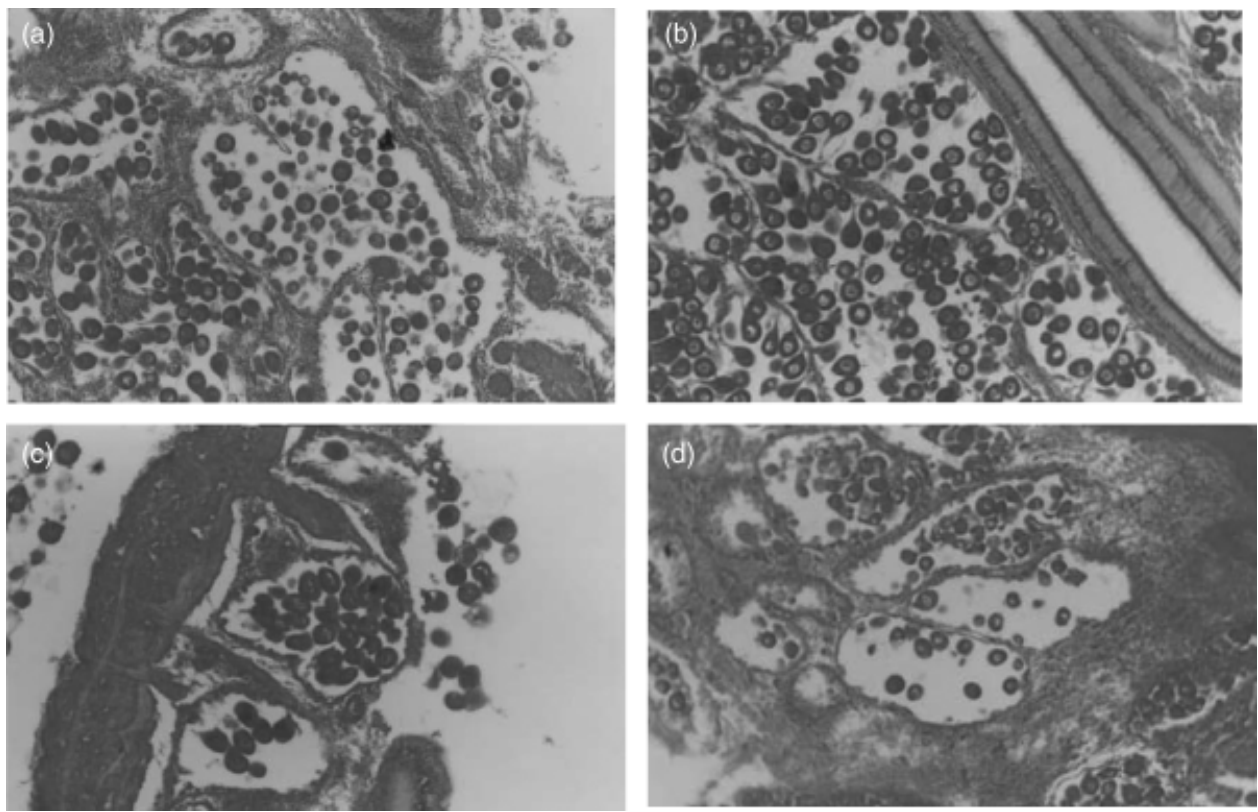

Figure 2 Female gonad Gafrarium tumidum. a. Early maturing gonad - All irregular ova $(<45 \mu \mathrm{m})$ b. Late maturing gonad - Most of the ova assuming spherical shape, few are irregular $(45-58 \mu \mathrm{m})$. c. Matured gonad-perfect spherical, densely packed ova $(>72 \mu \mathrm{m})$. d. Spent - Follicles are mostly empty with few residual ova $(>72 \mu \mathrm{m})$. Magnifications: a and b $10 \times 10 ; c$ and d $10 \times 5$.
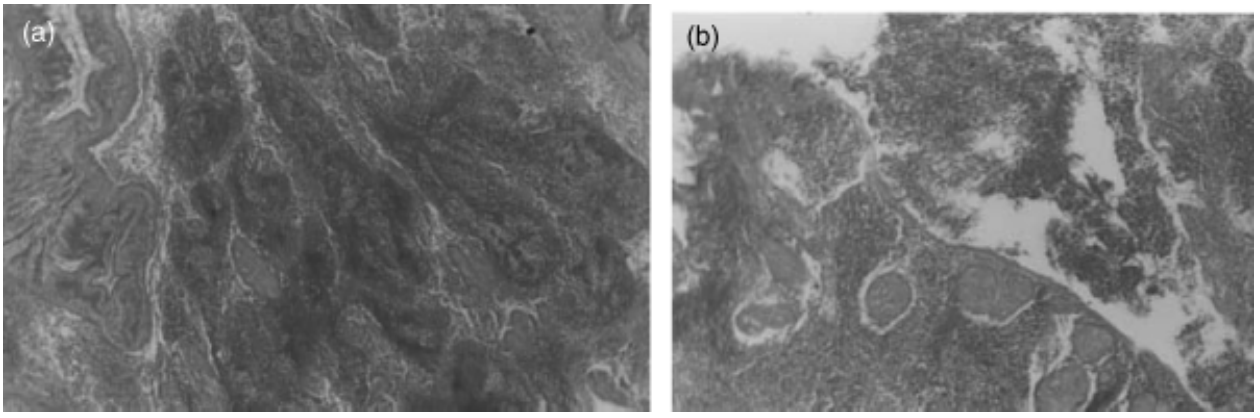

Figure 3 Male gonad Gafrarium tumidum. a. Matured - Follicles with densely packed spermatozoa. b. Spent - Follicles partly empty with residual spermatozoa. Magnifications: a and b $10 \times 10$.

Four different gonad stages were determined for females from the histological observations such as early maturing, late maturing, matured and spent and two stages, matured and spent, for males, respectively. Photomicrographs of various stages are given ([Fig. 2 (a-d) and Fig. 3 (a,b)]).

\section{Sex ratio}

Data on the monthly sex ratio is presented in Table 1. Female clams were more during 9 months with an annual value of $56.9 \%$. Males were found to be more in January, February and May. The $\chi^{2}$ values during different months are not significant except during October, December and January. The annual male: female ratio was 1:1.3 and it deviated significantly from the theoretical 1:1 ratio.

\section{Condition index based on dry and wet flesh weight}

The monthly average values (\%) of the CI for all groups combined based on dry meat weight and wet meat weights were calculated for males and females 
Table 1 Sex ratio of Gafrarium tumidum during 2000-2001

\begin{tabular}{|c|c|c|c|c|c|c|c|}
\hline Month & Males (nos.) & Females (nos.) & Male (\%) & Female (\%) & Ratio & $\chi^{2}$ value & ' $P$ ' value \\
\hline October'2000 & 23 & 50 & 31.51 & 68.49 & $1: 2.17$ & 9.9863 & $<0.005$ \\
\hline November & 28 & 39 & 41.79 & 58.20 & $1: 1.39$ & 1.8060 & $>0.05$ \\
\hline December & 27 & 53 & 33.75 & 66.25 & $1: 1.96$ & 8.45 & $<0.005$ \\
\hline January '2001 & 54 & 51 & 51.43 & 48.57 & $1: 0.94$ & 8.5714 & $>0.05$ \\
\hline February & 33 & 27 & 55.00 & 45.00 & $1: 0.82$ & 0.6 & $>0.05$ \\
\hline March & 41 & 48 & 46.07 & 53.93 & $1: 1.17$ & 0.5506 & $>0.05$ \\
\hline April & 30 & 47 & 38.96 & 61.04 & $1: 1.57$ & 3.7532 & $>0.05$ \\
\hline May & 34 & 28 & 54.84 & 45.16 & $1: 0.82$ & 0.5806 & $>0.05$ \\
\hline June & 41 & 50 & 45.06 & 54.94 & $1: 1.22$ & 0.8901 & $>0.05$ \\
\hline July & 32 & 53 & 37.65 & 62.35 & $1: 1.66$ & 5.1882 & $<0.05$ \\
\hline August & 19 & 31 & 38.0 & 62.00 & $1: 1.63$ & 2.88 & $>0.05$ \\
\hline September & 26 & 36 & 41.94 & 58.06 & $1: 1.38$ & 1.6129 & $>0.05$ \\
\hline Annual & 388 & 513 & 43.06 & 56.94 & $1: 1.32$ & 17.3418 & $<0.005$ \\
\hline
\end{tabular}

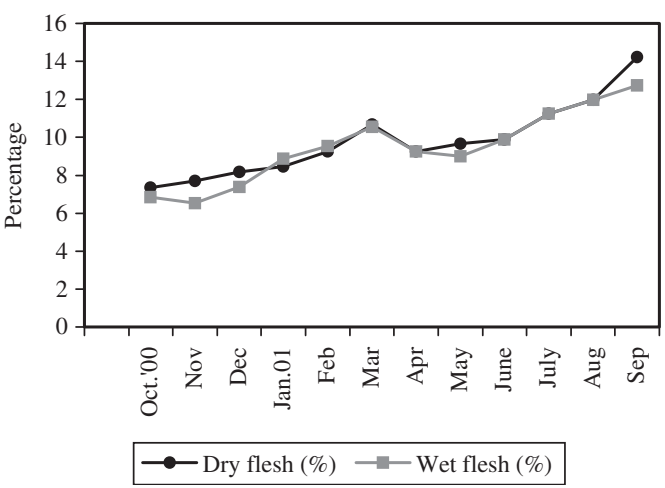

Figure 4 Condition index based on wet and dry flesh weight in male Gafrarium tumidum.

and presented (Figs. 4 and 5). The dry flesh weight varied between 8.82 (October) and 14.38 (August) with a mean value of 11.8 and those based on wet flesh weight ranged from 7.24 (November) and 14.14 (September) with a mean value of 10.19 for females. For males it was between 7.35 (October), 14.26\% (September) and 6.54 (November), 12.5\% (September), respectively. The values of the monthly average CI during the study period showed that the trends in the fluctuations of CI obtained by both the methods are comparable. The fluctuations in the $\mathrm{CI}$ in relation to the reproductive cycle showed that the CI values were high when most of the clams had either moderately or well-developed gonads. The low CI values coincided with the months during spawning.

\section{Water content}

The monthly average values of the water content recorded are presented (Table 2). The data revealed that

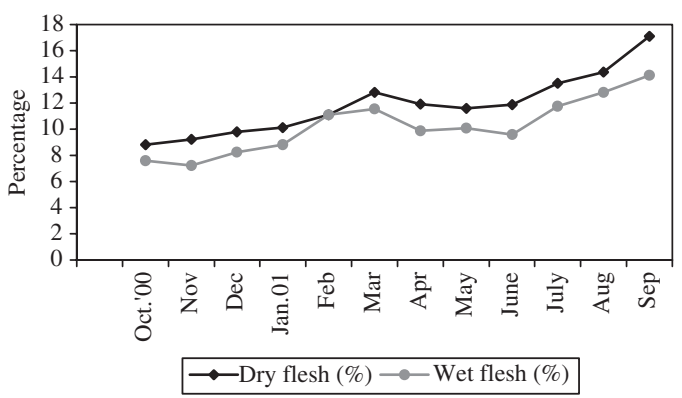

Figure 5 Condition index based on wet and dry flesh weight in female Gafrarium tumidum.

the difference between the values obtained for males and females was negligible. The highest values (89.6\% and $88.7 \%$ ) were observed during November coinciding with the peak spawning period. Thereafter the water content decreased and reached low values of $81.7 \%$ and $82.0 \%$ during March. A noticeable increase was observed during April (84.9\% and $84.6 \%$ ), coinciding with the minor spawning peak. During the rest of the months, the water content ranged from $82.6 \%$ to $87.2 \%$ and from $83.4 \%$ to $87.2 \%$ in males and females, respectively.

\section{Size at first maturity}

An examination of the percentage maturity stages of different size groups revealed that clams below the size group of 21.4-23.2 mm were either in the maturing stage or in a lesser percentage of fully matured state. Clams of $23.2 \mathrm{~mm}$ size and above were in the fully matured state. Hence, the mean value of the size group, i.e. $22.3 \mathrm{~mm}$, was considered as the size at which G. tumidum reaches its first maturity (Fig. 6). 
Table 2 Water content (\%) of male and female Gafrarium tumidum

\begin{tabular}{|c|c|c|c|c|c|c|c|c|c|c|c|c|}
\hline Sex/months & $\begin{array}{l}\text { October } \\
2000\end{array}$ & November & December & $\begin{array}{l}\text { January } \\
2001\end{array}$ & February & March & April & May & June & July & August & September \\
\hline Males & 86.8 & 89.6 & 87.2 & 85.3 & 82.6 & 81.7 & 84.6 & 84.9 & 85.2 & 85.7 & 85.0 & 86.1 \\
\hline Females & 85.5 & 88.7 & 86.6 & 85.6 & 83.4 & 82.0 & 84.9 & 85.4 & 86.3 & 86.0 & 86.7 & 87.2 \\
\hline
\end{tabular}

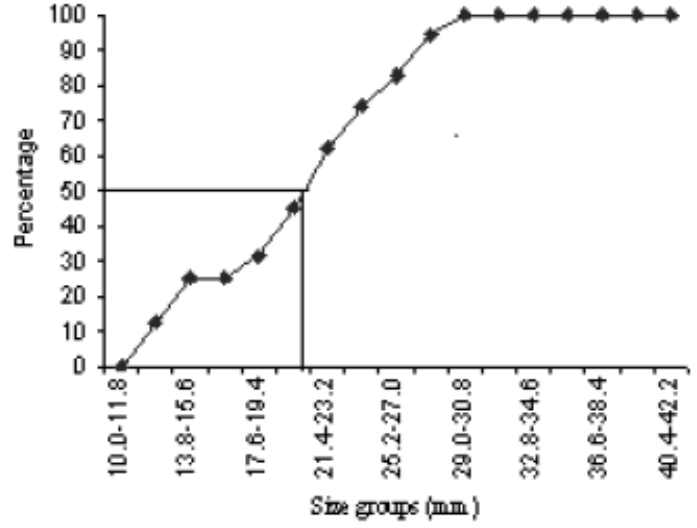

Figure 6 Size at first maturity in Gafrarium tumidum.

\section{Discussion}

Literature availability on Venus clam G. tumidum is very scanty. Hornell (1922) states, probably no other bivalve is so universally valued on the shores of Palk Bay as this cockle clam' which forms an excellent food for local fisher folks and shells for lime industry, and annually nearly five tons of these clams are collected at Pamban and Rameswaram area. It is also being exploited for food in many countries in the Indian Ocean. (Nayar \& Rao 1985). Hsieh, Chen \& Chang (1981) in their study underlines the importance of these clams potential for possible Mariculture in the littoral zones of Penghu, Taiwan. Understanding of the reproductive biology of any organism is a prerequisite for its suitability for aquaculture purpose.

The present study on G. tumidum clearly showed the availability of spent specimens along with different stages of maturity indicating the year-round breeding of this species when conditions are favourable. However, based on the lowest percentage of late maturing clams along with the highest percentage of spent clams during November, it may be concluded that this represents the peak period of spawning in this region. A secondary peak in April was also observed when considerable percentage of clams is found to be in the spent stage. The spawning season determined for the present species almost agrees with the finding for K. opima (Nagabhushanam \& Mane 1975).

Sreenivasan (1983) indicated that $M$. casta spawns during April-September in the Vellar estuary. Thangavelu and Poovannan (1994) found that M. casta occurring at Muttukadu was a continuous breeder with two intense spawning periods, one during May and another during September-October based on the high percentage of spent clam availability. Thangavelu and Sanjeevaraj (1985) found ripe clams in all the months showing spawning round the year, when environmental factors are favourable with peak periods during March-April, July-August and October-November. Narasimham et al. (1988) observed M. meretrix as a prolonged breeder (about 9 months) at Korampallam estuary and concluded that spawning occur when the temperature variation is narrow. They further inferred that there was absence of spawning during November-December when the salinity was very low $<10$ ppt.

It could be inferred that the members of veneridae are exhibiting either prolonged/continuous breeding with one to three spawning peaks in a year, even though these clams occupy different ecological habitats such as estuarine, backwater and marine. It is also evident that none of the members spawn actively during the monsoon period. In this study, it attained peak maturity during hotter seasons and higher salinities $\left(31.1-34.3^{\circ} \mathrm{C} \&\right.$ above $\left.30 \mathrm{ppt}\right)$ similar to the observations of Baron (1992). However, it spawned actively during November, corresponding to the northeast monsoon, which may be attributed to negligible dilution in seawater salinity (30.4 ppt) in the clam bed.

Sex ratio observed for G. tumidum indicated significant departure from the expected 1:1 ratio. The results obtained in the condition index are comparable with those of Narasimham (1988), in blood clam Anadara granosa. Water content showed only simple variations between male and females. Water content of animals, especially molluscs are an indicator of spawning period as observed by Alagarswami 
(1966), in Donax faba, Shunula (1989), in Anadara antiquata, which is comparable with the present results.

The size at first maturity estimated for G. tumidum (22.3 mm) compares well with the other venerid/arcid species studied. Sone (1994) and Baron (1992) estimated the size at first maturity of Gafrarium pectinatum in Tongon waters and G. tumidum from New Caledonia to be $20.0 \mathrm{~mm}$. Earlier estimations of size at first maturity for Katelysia opima were $24.7 \mathrm{~mm}$ (Kalyanasundaram 1982), 21-25 mm for Anadara rhombae (Natarajan \& George 1983) and for M. meretrix it was 21-26 mm (Jayabal 1984).

\section{Acknowledgments}

This study formed the part of the senior author's PhD thesis. He wishes to record his deep sense of thanks to the Director, CMFRI, Kochi, for his kind help and facilities. He also thanks the authorities of the Centre of Advanced Study in Marine Biology, Annamalai University, Parangipettai,Tamilnadu.

\section{References}

Abraham K.C. (1953) Observations on the biology of Meretrix casta (Chemnitz). Journal of Zoological Society of India $\mathbf{5}$, 163-190.

Alagarswami K. (1966) Studies on some aspects of biology of the wedge clam, Donax faba Gmelin from Mandapam Coast in the Gulf of Mannar. Journal of Marine Biological Association of India 8, 56-75.

Baron J. (1992) Reproductive cycles of the Bivalve Molluscs Atactodea striata (Gmelin), Gafrarium tumidum Roding and Anadara scapha (L.) in New Caledonia. Australian Journal of Marine and Freshwater Research 43, 393-402.

Hornell J. (1922) The common mollusks of South India, Madras. Fisheries Bulletin 14, 97-215.

Humason G.L. (1972) Animal Tissue Techniques, 3rd edn.W.H. Freeman, CA, USA, San Francisco.

Hsieh H.-L., Chen C.-P. \& Chang K.-H. (1981) The growth and production of Gafrarium tumidum (Roding) (Bivalve) in the littoral zone of Chiang-Mei, Penghu. Bulletin of the Institute of Zoology, Academia Sinica 20, 11-20.

Jayabal R. (1984) Studies on Meretrix meretrix (Linn.) (Mollusca: Bivalves: Veneridae) from Portonovo waters. $\mathrm{PhD}$ thesis. Annamalai University, India, 110pp.

Kalyanasundaram M. (1982) Studies on Katelysia opima (Gmelin) (Mollusca: Bivalvia:Veneridae) from the Vellar Estuary. MPhil thesis, Annamalai University, 78pp.
Kripa V. (1997) Studies on the biology and experimental culture of the rock oyster Saccostrea cucullata (Born). PhD thesis, Cochin University of Science and Technology, 218pp.

Nagabhushanam R. \& Mane U.H. (1975) Reproduction and breeding of the clam Katelysia opima in the Kalbadevi Estuary at Ratnagiri, West coast of India. Indian Journal of Marine Science 4, 86-92.

Narasimham K.A. (1988) Biology of the blood clam Anadara granosa (Linnaeus) in Kakinada Bay. Journal of Marine Biological Association of India 30, 137-150.

Narasimham K.A., Muthiah P., Gopinathan C.P. \& Gandhi A.D. (1988) Biology of the great clam Meretrix meretrix (Linnaeus) in the Korampallam creek, Tuticorin. Indian Journal of Fisheries 35, 288-293.

Natarajan R. \& George J. (1983) Reproduction in the edible ribbed clam Anadara rhombae (Born) from the backwaters of Porto Novo. Indian Journal of Marine Science 12, 90-95.

Nayar K.N. (1955) Studies on the growth of wedge clam: Donax (Latoma) cuneatus. Linnaeus. Indian Journal of Fisheries 2, 325-348.

Nayar N.K. \& Rao S.K. (1985) Molluscan fisheries of India. Marine Fisheries Information Service, Cochin. Bulletin No. 61, 1-7 pp.

Rao K.V. (1952) Studies on the growth of Katelysia opima (Gmelin). Proceedings of Indo Pacific Fisheries Council. Sec II: 1-9 pp.

Rao K.S. (1967) Annual reproductive cycle of the Wedge clam Donax cuneatus (Linnaeus) Journal of Marine Biological Association of India. 9, 141-146.

Ropes J.W. (1968) Reproductive cycle of the surf clam, Spisula solidissimus in offshore New Jersey. Biological Bulletin 135, 345-365.

Snedecor G.W. \& Cochran W.G. (1967) Statistical Methods, 6th edn. Ames, IA: Iowa State University Press. 593pp.

Sone S. (1994) Breeding season of Tongon shellfish 1. Venus clam Gafrarium sp. Fisheries Research Bulletin. Tonga 1, 13-19.

Sreenivasan P.V. (1983) Distribution of Meretrix casta (Chemnitz) in Vellar Estuary. Proc. Symp. Coastal Aquaculture. Marine Biological Association of India 2, 561-563.

Shunula J.P. (1989) Length weight relationship in the bivalve Anadara antiquata (Linnaeus 1758). Journal of Marine Biological Association of India 31, 425-429.

Thangavelu R. \& Poovannan P. (1994) Some aspects of biology of the clam Meretrix casta (Chemnitz) in Muttukadu Backwaters. Journal of Marine Biological Association of India 36, 77-80.

Thangavelu R. \& Sanjeevaraj P.J. 1985 Fishery and biology of the clam Meretrix casta (Chemnitz) in the Pulicat Lake. Journal of Marine Biological Association of India 27, $75-83$. 